\title{
Seasonal variations of species composition and abundance of zooplankton in Ehoma Lake, a floodplain lake in Nigeria
}

\author{
Okechukwu. I. Okogwu \\ Applied Biology Department, Ebonyi State University, PMB 53, Abakaliki, Ebonyi State, Nigeria; \\ okeyokogwu@yahoo.com
}

Received 31-I-2009. Corrected 21-VI-2009. Accepted 21-VII-2009.

\begin{abstract}
Ehoma Lake is among the important breeding sites of the major fishes in the Mid-Cross River, Nigeria. The juveniles of these fishes are solely dependent on zooplankton, which has not been studied previously. I studied monthly the lake's physico-chemical variables and zooplankton composition in three stations (littoral, sub-littoral and pelagic) from March 2005 to August 2006. Sixty-seven zooplankton species (42 rotifers, 19 cladocerans and 6 copepods) were identified. Daphnia obtusa Kurz, Keratella valga Ehrenberg, Keratella ticinensis Callerrio, Keratella hiemalis Carlin, Brachionus dimidiatus Bryce and Lecane candida Hauer and Murray are new records for Nigeria. The dominant zooplankters were Diaphanosoma excisum Kurz and Moina micrura Kurz. There was an inverse relationship between species richness and abundance. Richness was highest in the dry season while peak zooplankton abundance was recorded in the rainy season. Zooplankton abundance and species richness decreased progressively from the littoral to the pelagic station while the Shannon-Weaver diversity index varied from 0.68 to 1.28 without a clear seasonal trend. There is a succession pattern: rotifers that are dominant in the dry season are replaced by cladocerans in the rainy season. This succession was greatly influenced by seasonal flooding of the lake. As no previous information on the zooplankton of the lake is available, this study provides baseline data on the lake's zooplankton. Rev. Biol. Trop. 58 (1): 171-182. Epub 2010 March 01.
\end{abstract}

Key words: zooplankton, species richness, Daphnia obtusa, abundance, Cross River, floodplain, season.

Zooplankton organisms are identified as important components of aquatic ecosystems. They help in regulating algal and microbial productivity through grazing and in the transfer of primary productivity to fish and other consumers (Dejen et al. 2004). By grazing on phytoplankton and bacteria they help in improving water quality. Therefore, zooplankton are considered indicators of water quality (Pinto-Coelho et al. 2005). However, the responses of zooplankton to water quality variation are ecosystem and species dependent and vary within and between lakes (Ravera 1996). Studies on Nigerian and other tropical zooplankton include Bidwell \& Clarke (1977), Jeje \& Fernando (1986), Egborge et al. (1994),
Uku \& Mavuti (1994), Akinbuwa \& Adeniyi (1996), Aoyagui \& Bonecker (2004), Mwebaza-Nadwula et al. (2005), Mergaey et al. (2006). High species richness and abundance are known to occur in floodplain lakes (Serger et al. 1993) and this is crucial to sustainable fish productivity of adjoining rivers. Fishes of floodplain rivers are known to migrate seasonally to floodplain lakes to breed. The juveniles of some these fishes are obligate zooplanktivores (Mwebaza-Ndawula 1994) and depend solely on zooplankton for their survival.

Several limnological studies in the tropics have shown that the zooplankton of floodplain lakes are highly responsive to changes in environmental variables that include dissolved 
oxygen (Aka et al. 2000), pH (Gilbert 1988), flood pulse, environmental morphometry, connectivity and lake width and depth (Masundire 1994, Dejen et al. 2004). The species composition and richness of zooplankton in floodplain lakes vary remarkably between seasons in response to changes in these environmental variables. Seasonal flooding of these lakes tends to bring about environmental changes which ultimately influence the biotic interactions between populations of floodplains (Aoyagui \& Bonecker 2004). Studies on other tropical floodplains associate peak zooplankton population with rainy season (Masundire 1994).

Information on the zooplankton of the Cross River floodplain lakes is rarely available despite their role in supporting the booming fish and shrimp productivity of the Cross River. This study was therefore undertaken to (i) provide a baseline data on the zooplankton of Ehoma Lake and (ii) examine spatial and seasonal variations in species composition and abundance of the lake's zooplankton.

\section{MATERIALS AND METHODS}

Study site: The study area (Ehoma Lake) is located in the Middle Cross River floodplain. It lies at $5^{\circ} 48^{\prime} \mathrm{N}, 7^{\circ} 58^{\prime} \mathrm{E}$ and an altitude of $50 \mathrm{~m}$ above sea level. It is not directly connected to any river but benefits from seasonal flooding by the Cross River during the rainy season. The water level varies between 1.3 and $7.0 \mathrm{~m}$. The lake is fished annually in February. The climate is tropical and details can be found in Moses (1979) and Okogwu (2008). Four seasons can be distinguished into dry (December to March), pre-rainy (April-May), rainy (June-September) and post-rainy (October-November).The catchment area of the lake is agricultural land but recent development of unplanned towns near the lake could lead to insidious deposition of sewage in the lake.

Sampling: Samples for zooplankton and physicochemical analysis were collected monthly from three stations in Ehoma
Lake between March 2005 and August 2006. Samples were collected from the littoral, sublittoral and pelagic stations. Temperature, $\mathrm{pH}$, Dissolved Oxygen $\left(\mathrm{DO}_{2}\right)$, percentage saturation of oxygen $\left(\% \mathrm{O}_{2}\right)$, conductivity and Total Dissolved Solids (TDS) were measured in situ using portable Hanna field metres. Transparency was determined using secchi disc. Biological Oxygen Demand (BOD) was determined according to the methods of APHA (1992). At each station, zooplankton was collected by three horizontal tows over a distance of $100 \mathrm{~m}$ using $0.5 \mathrm{~m}$ diameter $(45 \mu \mathrm{m}$ mesh size $)$ net. The three samples were pooled and preserved in $4 \%$ formalin. The following taxonomic keys were used in zooplankton identification: Rotifera (Koste 1978, Segers 1993, Segers, et al. 1993), Cladoceran (Jeje \& Fernando 1986, Korovchinsky 1992), Copepoda (Jeje 1988, Williamson 1991, Ueda \& Reid 2003). Quantitative estimate of zooplankton groups was done under the light microscope at 100x magnification. Five sub-samples of $15 \mathrm{ml}$ each were usually counted from each collected sample and the mean density used to compute abundance. All the crustaceans in the sample were counted as recommended by Downing \& Rigler (1984). At least 100 individuals of rotifers and developmental stages were counted in order to reduce the coefficient of variation to a maximum of $10 \%$.

Two-way ANOVA was used to analyse statistical difference in species richness and abundance of zooplankton between stations (littoral, sub-littoral and pelagic) and seasons (dry, prerainy, rainy and post-rainy). Shannon-Weaver index (Shannon \& Weaver 1949) and species richness (total number of species encountered in a sample) were used to determine diversity.

\section{RESULTS}

Environmental data: Conductivity and Total Dissolved Solids (TDS) were low, ranging from 11 to $42 \mu \mathrm{Scm}^{-1}$ and 5 to $20 \mathrm{mgL}^{-1}$ respectively. These decreased in value from littoral to pelagic station and dry to the rainy season (Table 1). The $\mathrm{pH}$ showed minor 
TABLE 1

Mean, minimum and maximum values of selected environmental parameters at Ehoma Lake

\begin{tabular}{|c|c|c|c|c|}
\hline \multirow{2}{*}{ Variables } & \multirow{2}{*}{ Mean \pm SD } & \multirow{2}{*}{ Range } & \multicolumn{2}{|c|}{ Month } \\
\hline & & & Minimum & Maximum \\
\hline $\mathrm{pH}$ & $6.46 \pm 0.31$ & $5.6-6.8$ & Feb & Aug \\
\hline DOX $(\%)$ & $45.33 \pm 29.31$ & $3-102$ & Jun & Dec \\
\hline Conductivity $\left(\mu \mathrm{Scm}^{-1}\right)$ & $22.89 \pm 7.41$ & $11.0-42$ & Jun & Mar \\
\hline $\operatorname{TDS}\left(\mathrm{mgL}^{-1}\right)$ & $10.78 \pm 3.51$ & $5.0-20$ & May & Mar \\
\hline $\mathrm{BOD}\left(\mathrm{mgL}^{-1}\right)$ & $4.31 \pm 1.30$ & $3.4-7.6$ & Jun & May \\
\hline
\end{tabular}

Values are derived from mean monthly values in the three stations

fluctuation from 5.6 to $6.8, \mathrm{pH}$ increased from dry to rainy season and from littoral to pelagic station. The lake water was turbid; Secchi disc transparency increased with increase in rainfall from $0.1-1.2 \mathrm{~m}$, with highest and lowest values in October 2005 and March 2005 respectively. Water temperature decreased from $31.7^{\circ} \mathrm{C}$ during the dry season to $25.1^{\circ} \mathrm{C}$ in the rainy season. Similarly, Dissolved Oxygen (DO) and Biological Oxygen Demand (BOD) decreased from dry to rainy season. Dissolved Oxygen showed remarkably significant seasonal variation $(\mathrm{F}=4.5, \mathrm{p}<0.01)$ with critical low value of $0.8 \mathrm{mgL}^{-1}$ during the rainy season in the littoral station (Fig. 1). Spatially, dissolved oxygen, temperature and BOD increased from the littoral to the pelagic station.

Species Composition: Sixty-seven (67) zooplankton species were encountered in the lake, amongst these are 42 rotifers, 19 cladocerans and 6 copepods (Table 2). Most of the rotifers were rare and seen in samples collected during the dry and post-rainy seasons only with the exception of Brachionus calyciflorus calyciflorus Pallas, Brachionus caudatus Barrois and Daday, Keratella quadrata O. F Muller and Keratella tropica tropica Apstein. The rotifers mainly the Brachionidae and Lecanidae were numerically dominant during the dry, prerainy and post-rainy seasons when dissolved oxygen and temperature was high. They also recorded the highest number of species during these periods with peak values during the dry season in three stations. Conversely the species richness and density of cladocerans were low during the dry season. Peak cladoceran density was attained during the rainy season when they attained predominant status. During this season, Moina micrura Kurz and Diaphanosoma excisum Sars were co-dominant and the densities of rotifers and copepods were very low. The copepods as a group rarely dominated the zooplankton of the lake but attained maximum and minimum numerical values in the three stations during the dry and rainy season respectively. One cladoceran (Daphnia obtusa Kurz) and five rotifers (Keratella valga Ehrenberg, Keratella ticinensis Callerrio, Keratella hiemalis Carlin, Brachionus dimidiatus Bryce and Lecane candida Hauer and Murray) are new records for Nigeria and were identified in samples collected in the littoral station. Daphnia obtusa Kurz was seen in samples taken during the rainy season only.

Seasonal trends: Seasonal variations in the density of major zooplankton groups, species richness and diversity showed similar trends in the three stations. Species richness declined in value from the littoral to pelagic station and from dry to rainy season (Fig. 2). The highest species richness (66) was recorded during the dry season in the littoral station while the lowest number (29) was recorded during the rainy season in the pelagic station. Species richness varied significantly between season and stations $(\mathrm{F}=4.58, \mathrm{p}<0.01)$. In contrast to species richness, peak zooplankton abundance was attained during the rainy season 

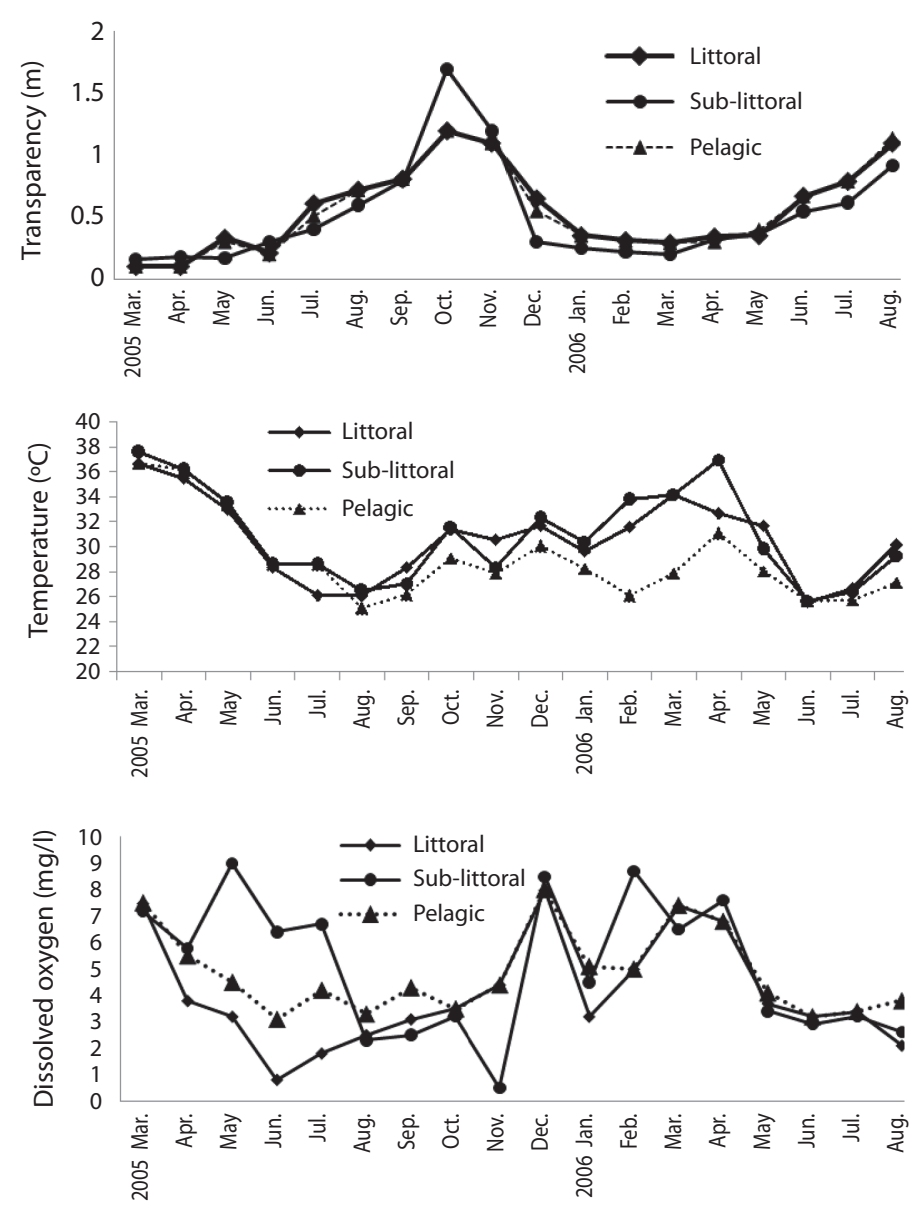

Fig. 1. Seasonal variation in temperature, Dissolved Oxygen (DO) and transparency in the three stations. Sergio: a esta figura 1 habría que corregir la unidad de Dissolved oxygen a $\mathrm{mg} / \mathrm{L}$ por favor

in all the stations and minimum values during the post-rainy seasons. However, inter-station variation in abundance followed a similar trend as species richness with decline in zooplankton population from littoral to pelagic stations (Fig. 3). Total zooplankton abundance did not vary significantly between stations $(\mathrm{F}=0.09$, $\mathrm{p}<0.05)$ but varied significantly between seasons $(\mathrm{F}=5.29, \mathrm{p}<0.03)$. The highest total abundance ( $>11370$ ind. $\left.\mathrm{L}^{-1}\right)$ was recorded during the rainy season in the littoral station and the lowest (2500ind. $\mathrm{L}^{-1}$ ) occurred in the pelagic station during the post-rainy season. High total abundance values during the rainy season were associated with numerical dominance of the cladocerans. Cladocerans accounted for over $58 \%$ of zooplankton population in all the stations during the rainy season. The cladocerans, Moina micrura and Diaphanosoma excisum were co-dominant in the lake. Peak values attained by these species during the rainy season declined rapidly during the post-rainy season to the lowest level during the dry season (Fig. 4). Amongst the rotifers, the perennial species, Brachionus calyciflorus calyciflorus Pallas, Brachionus calyciflorus dorcas Gosse, Keratella quadrata O. F Muller and Keratella tropica tropica Apstein displayed remarkable 
TABLE 2

Occurrence of zooplankton in four seasons in Ehoma Lake

Taxa
Taxo-Rainy Rainy Post rainy

Rotifera

Order: Ploima

Family: Asplanchnidae

Asplanchena herricki De Guerne, 1850

Family: Branchionidae

Anuraeopsis navicula navicula Rousselet, 1910

Brachionus angularis Gosse, 1851

Brachionus calyciflorus calyciflorus Pallas 1776

Brachionus calyciflorus dorcas Gosse, 1883

Brachionus caudatus Barrois and Daday, 1894

Brachionus urceolaris bennini O. F. Muller, 1786

Branchionus dimidiatus Bryce

Branchionus leydigi rotundus Rousselet, 1907

Branchionus plicatilis var asplanchnoides O. F. Muller, 1786

Kellicottia longispina longispina Kellicott, 1896

Keratella americana Carlin, 1943

Keratella hiemalis Carlin

Keratella quadrata O. F Muller, 1786

Keratella ticinensis Callerrio, 1920

Keratella tropica tropica Apstein, 1907

Keratella tropica var reducta Fadeew

Keratella valga Ehrenberg, 1834

Lophocharis oxysternon Gosse

Family: Euchlanidae

Euchlanis dilatata dilatata Ehrenbreg, 1832

Family: Lecanidae

Lecane acronychal Hauer and Murray, 1913

Lecane aegana Harring

Lecane candida Hauer and Murray

Lecane clara Bryce

Lecane elongata Hauer and Murray

Lecane leontina Turner, 1892

Lecane luna Muller, 1776

Lecane papuana Murray, 1913

Lecane tenuiseta Harring, 1914

Lecane tryphema

Family: Synchaetidae

Polyarthra dolichoptera Idelson, 1925

Polyarthra vulgaris Carlin, 1943

Family: Trichocercidae

Trichocerca cylindrica Imhof, 1891

Trichocerca elongata tchadiensis Pourriot, 1968

Trichocerca similis Hauer, 1965

Order: Conochilidae

Family: Filinidae

Family Hexarthridae

Hexarthra mira mira Hudson, 1871

Family: Testudinellidae

Testudinella emaginula Stenroos 
TABLE 2 (Continued)

Occurrence of zooplankton in four seasons in Ehoma Lake

\begin{tabular}{ll} 
Taxa & \multicolumn{2}{c}{ Season } \\
Pry Painy
\end{tabular}

\section{Family: Trichotriidae}

Macrochaetus collinsis var braziliensis Gosse

Macrochaetus sericus Thorpe

Nauplii

Cyclop nauplii

Calanoid nauplii

\section{Order Cladoceran}

Family: Bosminidae

Bosmina longirostris O. F. Muller, 1785

Family Chydoridae

Alonella excisa excisa Fischer, 1854

Alona costata Sars, 1862

Alona quadrangularis O. F. Muller, 1785

Alona rectangula Sars, 1862

Alona sp.

Chydorus sphaericus O. F. Muller, 1785

Euryalona orientalis Daday, 1898

Family: Daphnidae

Ceriodaphnia dubia Richard, 1894

Leberis sp.

Family: Macrothricidae

Ilyocryptus spinifer Herrick, 1892

Macrothrix sp

Macrothrix triserialis Brady, 1848

Family: Moinidae

Moina dubia Richard, 1874

Moina micrura Kurz, 1874

Family: Sididae

Diaphanosoma excisum Sars, 1885

Diaphanosoma sarsi Richard, 1895

\section{Order: Calanoida}

Family: Diaptomidae

Tropodiaptomus incognitos Dussart and Gras, 1966

Tropodiaptomus processifer Kiefer, 1927

Order: Cyclopoida

Family: Cyclopidae

Mesocyclops bodanicola Keifer, 1928

Mesocyclops leuckarti Claus, 1857

Thermocyclops decipiens Kiefer, 1929

Thermocyclops neglectus Sars, 1901

$\begin{array}{cccc}\dagger & - & - & \dagger \\ \dagger & - & \dagger & - \\ \dagger \dagger & \dagger & \dagger & \dagger\end{array}$

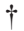

$\dagger+\dagger$
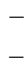

$-$

$$
-
$$

$+1$

$\begin{array}{cc}\dagger & - \\ \dagger+ & \dagger\end{array}$

$+$

$-\quad+\dagger \quad+$

$-=$ not found; $\dagger=$ rare; $\dagger \dagger=$ frequent; $\dagger \dagger \dagger=$ abundant. 


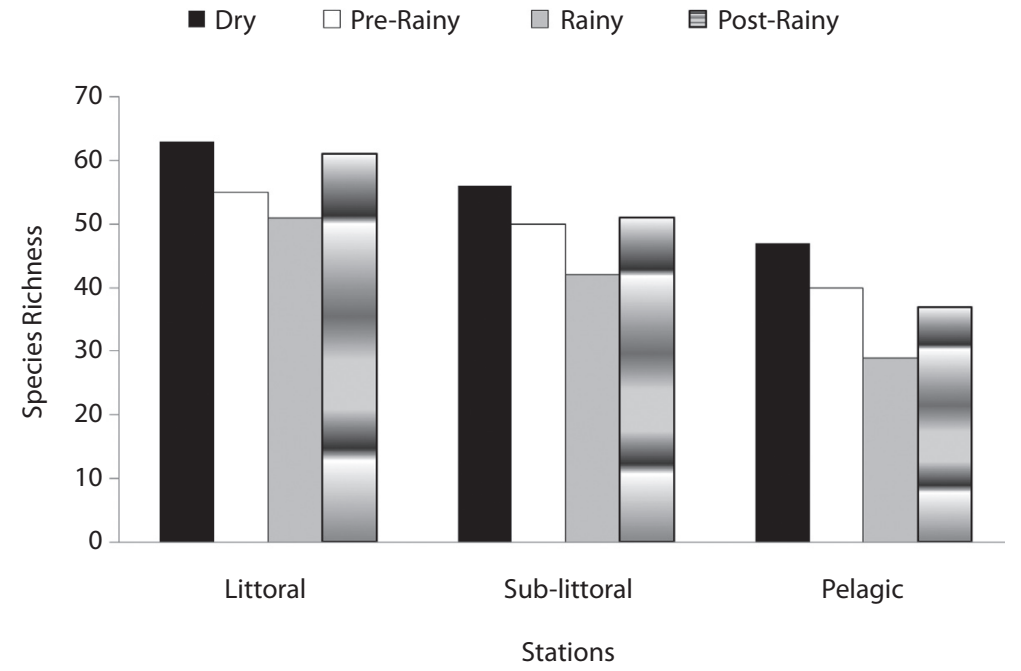

Fig. 2. Seasonal variations in species richness in three stations of Ehoma Lake.

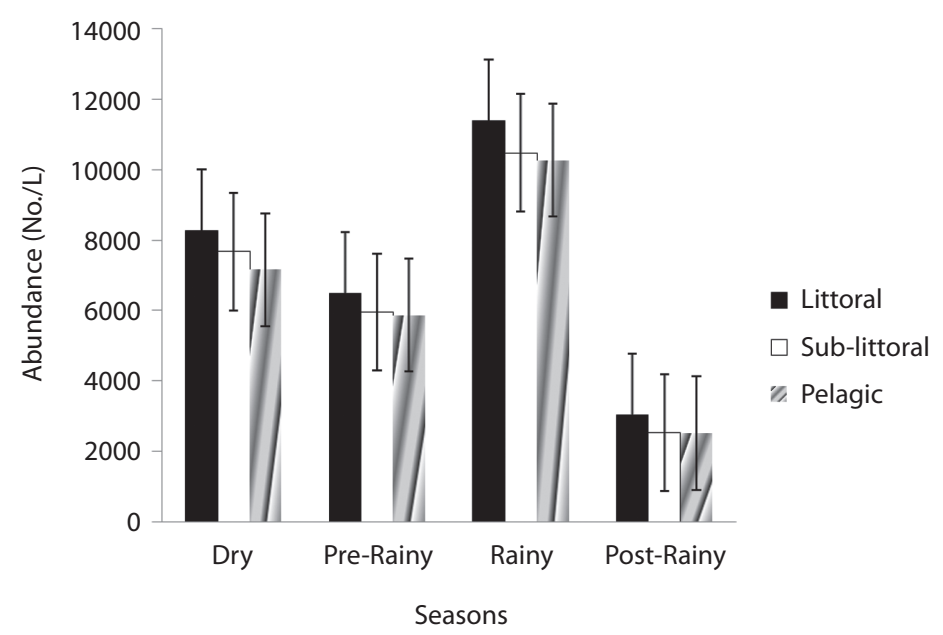

Fig. 3. Seasonal variations in zooplankton abundance in the three stations of Ehoma Lake.

density peak during the dry season. The populations of these species declined gradually during the post-rainy season to attain the lowest level during the rainy season and gradually increased again during the post-rainy season. Lecane leontina Turner, Filinia opoliensis Zacharias, Trichocerca cylindrica Imhof and Trichocerca elongata tchadiensis Pourriot though perennial maintained very small populations throughout the study.
The copepods attained peak values during the dry season when Thermocyclops neglectus Sars was predominant. The timing and attainment of maximum increases was similar in the three stations. Maximum dry season values were accompanied by gradual decline in population to the lowest values during the post rainy season. As shown in Fig. 5, diversity values did not show significant $(\mathrm{P}=2.18$, $\mathrm{p}<0.05)$ important fluctuations but monthly 
Littoral zone

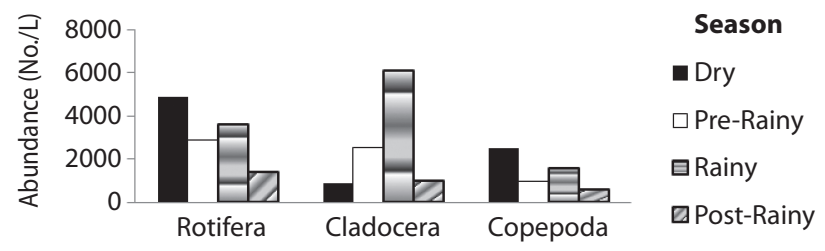

Sub-littoral zone
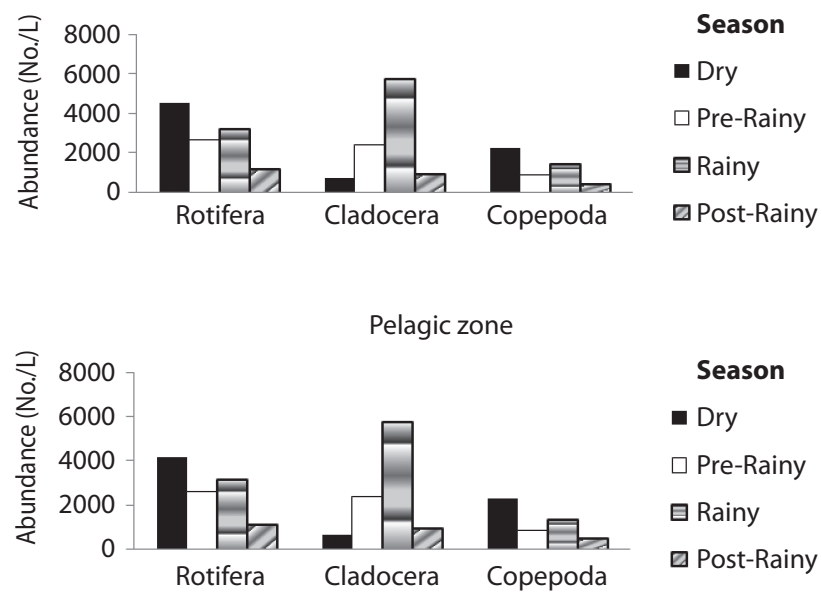

Fig. 4. Seasonal variations in the abundance of Rotifera, Cladocera and Copepoda in the three stations.

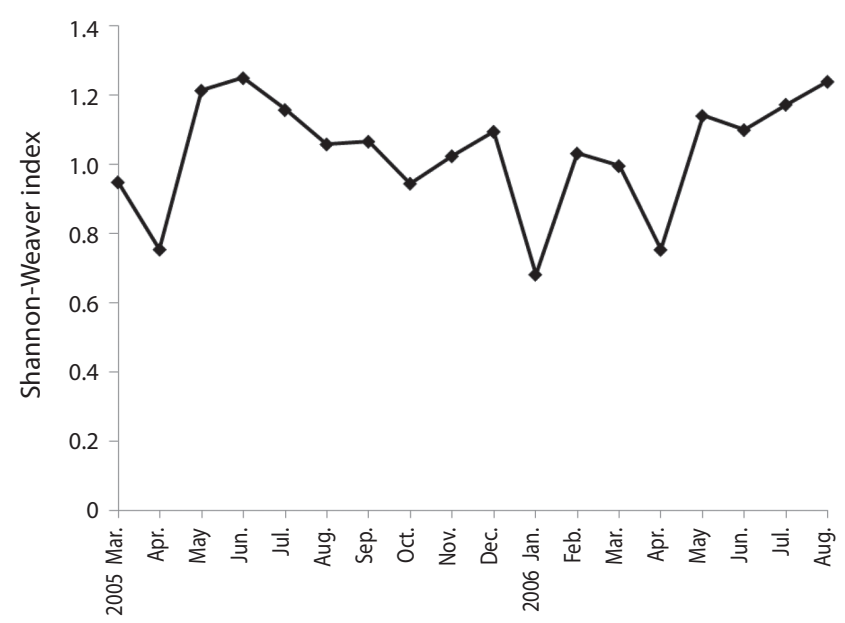

Fig. 5. Seasonal variation in Shannon-Weaver diversity index in Ehoma Lake. 
variations resulted in higher mean diversity during the rainy season when the cladocerans were dominant.

\section{DISCUSSION}

In this study, 42 rotifers, 19 cladocerans and 6 copepods species were identified. Dominance by rotifers is characteristic of tropical lakes and this has been reported in the studies of Bidwell \& Clarke (1977), Egborge (1981) and Mwebaza-Nadwula (2005). Lecanidae and Brachionidae are usually represented by the highest number of species and the frequently encountered genera include Brachionus, Lecane and Keratella (Aoyagui \& Bonecker 2004). Identification of new rotifer and cladoceran species underscores the importance of regular studies of the zooplankton of tropical freshwater and keeps faith with the prophetic statement of Dumont (1994) that as the number of studies on tropical waters increase there will be commensurate increase in the number of species.

Peak in total zooplankton abundance was recorded during the rainy season (June-September). Population peaks in rainy seasons have also been reported by Saint-Jean (1983), Masundire (1994) and Okogwu \& Ugwumba (2006). This coincided with the period of low temperature and flooding of the lake. Seasonal flooding of the lake may have contributed positively to zooplankton population growth in three ways; firstly, the influent water is likely to bring in nutrients from the river and drained agricultural land and also help in mixing autochthonous nutrients amongst the different strata of lake. These nutrients will trigger off increase in phytoplankton production and consequently zooplankton productivity. Secondly, the flood waters may also inoculate the lake with riverine zooplankton and species recruited from other flooded lakes and ponds within the Cross River floodplain systems (as most the ephemeral ponds and lakes within the middle Cross River were flooded at the same time). This may be responsible for the brief appearance of Alonella excisa excisa Fisher,
Alona quadrangularis O.F. Muller, Alona rectangular Sars, Daphnia obtusa Kurz and Moina dubia Kurz in the littoral station during the flood period. These species may have been transported from other lakes within the Cross River floodplain and were unable to establish themselves in limnetic zone. Hence the species richness of cladocerans was more inflated by flooding than any other group. Thirdly, influent waters are likely to bring in cooler waters from the river. Low water temperature and other environmental conditions are prerequisites to the hatching of resting cladoceran eggs in natural water (Mergeay et al. 2006). Furthermore, during the rainy season, the littoral zone is expanded by over $500 \%$ in area. This could also lead to hatching of resting zooplankton eggs deposited in previously dry land. This third factor may explain the dominance of the cladocerans during the rainy season. Dejen et al. (2004) attributed the dominance of cladocerans in Lake Tana to the rapid hatching of resting egg.

The dominance of cladocerans during the rainy season may be ascribed to multiple factors that include low water temperature, high nutrient condition, food availability and hatching of egg. Under optimum environmental conditions, cladocerans tend to out-compete the rotifers (Gilbert 1988). As water quality deteriorated and temperature and acidity increased during the dry season, the population and species richness of cladocerans declined. This relieved the suppressed rotifer population leading to their predominance during the dry season. Rotifers and small copepods are known to be more tolerant of adverse environmental conditions than the cladocerans (Auclair et al. 1993, Hannson et al. 2007). However, acidiophilic cladocereans like Moina micrura and Bosmina longirostris were persistent during the dry season.

Seasonal succession of zooplankton communities in the tropics has been attributed to a number of factors such as the environmental characteristics of the water, predation, quality and quantity of edible algae and competition (Onwudinjo \& Egborge 1994, Ovie \& Adeniji 
1994). A succession pattern where cladocerans dominate during the rainy season is typical of Nigerian inland waters such as Asejire Lake (Egborge 1981) and Lamingo dam (Khan \& Ejike 1984). Onwudinjo \& Egborge (1994) attributed low rotifer density during the rainy season to the negative influence of turbulent flood waters. It is very unlikely that low rotifer density during the wet season in this study was due to turbulent flood waters, rather a more plausible explanation is that predation and unfavourable competition with the cladocerans were responsible for low rotifer population. Nevertheless, Brachionus calyciflorus calyciflorus Pallas and Keratella tropica tropica Aspein were able to maintain high population during the wet season suggesting that they are resistant to suppression by the cladocerans.

The lowest zooplankton abundance was recorded during the post-rainy season (when all the zooplankton groups had very low values). The main reason for this is not immediately known but we believe that predation by juvenile fish may have contributed to the decline in zooplankton. Concurrent samples taken showed high density of the juveniles of Oreochromis niloticus and Clarias spp. during the post-rainy season (Okogwu 2008). The juveniles of Oreochromis spp. and Clarias spp. are obligate zooplanktivores (Mwebaza-Ndawula 1994, Ovie \& Ovie 2002). Fish predation on zooplankton during this season may have led to low zooplankton population.

In contrast to abundance, species richness was higher during the dry and post-rainy seasons than in the rainy and pre-rainy seasons. High rotifer species richness was also recorded during these seasons in contrast to the findings of Ayoagui \& Bonecker (2004). This may be ascribed to low population of cladocerans and the relief of the rotifers from competitive suppression by the cladocerans. Aoyagui \& Bonecker (2004) stated that zooplankton diversity can be increased by the removal of competitively dominant species. Shannon-Weaver diversity index varied from 0.68 to 1.28 and did not vary significantly between seasons which are characteristics of stable physico-chemical conditions. This suggests that the lake is not under serious pollution threat presently.

In conclusion, the results of this study revealed zooplankton species new to Nigerian inland waters and inverse relationship between the abundance of Cladocerans and Rotifers during the rainy and dry seasons. Species richness benefited from removal of dominant Cladocerans which in turn were adversely affected by increase in temperature and acidity. However a number of questions are raised by this study: (i) to what degree does the annual fishing festival impact on the zooplankton community structure of the lake? (ii) Are resting eggs present in the dried portions of the lake during the dry season? and (iii) How do juvenile and adult fishes affect the community structure of zooplankton? A regular study on the lake is hereby advised in order to understand the impact of increased anthropogenic activities around the lake, annual fishing and global warming on the zooplankton community structure of the lake.

\section{ACKNOWLEDGMENT}

I am grateful to Alex Ugwumba for his guidance during the study and to Henri Dumont for helping with the identification of the crustaceans. David Utom's assistance during field sampling is also acknowledged. International Society of Limnology (SIL) provided sponsorship through the Tonolli fund.

\section{RESUMEN}

El lago Ehoma, situado en la mitad del río Cross, es uno de los lugares de reproducción de las principales especies de peces del río. Los juveniles de estos peces dependen exclusivamente del zooplancton, sin embargo poco se sabe sobre este recurso en el lago. En este estudio, las variables físico-químicas y del zooplancton del lago fueron estudiadas mensualmente en tres estaciones (litoral, sub-litoral y pelágica), de marzo de 2005 a agosto de 2006 . Fueron identificadas 67 especies de zooplancton (42 rotíferos, 19 cladóceros y 6 copépodos). Daphnia obtusa Kurz, Keratella valga Ehrenberg, Keratella ticinensis Callerrio, Keratella hiemalis Carlin, Brachionus dimidiatus Bryce y Lecane candida Hauer y Murray son nuevos registros para Nigeria. Las especies dominantes fueron Diaphanosoma excisum Kurz y Moina micrura Kurz. Hubo una relación 
inversa entre la riqueza de especies y la abundancia. La riqueza de especies fue mayor en la estación seca, mientras que la abundancia de zooplancton registró su mayor valor en la estación lluviosa. La abundancia y riqueza de especies de zooplancton disminuyó progresivamente desde la estación del litoral a la pelágica, mientras que el índice de diversidad de Shannon-Weaver varió de 0.68 a 1.28 , sin una clara tendencia estacional. Se encontró un patrón de sucesión: los rotíferos, dominantes en la estación seca, fueron reemplazados por cladóceros en la estación lluviosa. Esta sucesión estuvo fuertemente influenciada por las inundaciones estacionales del lago. Al no haber información disponible sobre el zooplancton de este lago, este estudio proporciona los primeros datos de referencia.

Palabras clave: zooplancton, riqueza de especies, Daphnia obtusa, abundancia, Río Cross, planicie de inundación, estación

\section{REFERENCES}

Aka, M., M. Pagano, L. Saint-Jean, R. Arfi, M. Bouvy, P. Cecchi, D. Corbin \& S. Thomas. 2000. Zooplankton variability in 49 shallow tropical reservoirs of Ivory Coast (West Africa). Internat. Rev. Hydrobiol. 85: 439-504.

Akinbuwa, O. \& I.F. Adeniyi. 1996. Seasonal variation, distribution and interrelationships of rotifers in Opa Reservoir, Nigeria. Afr. J. Ecol. 34: 351-363.

Aoyagui, A.S.M. \& C.C. Bonecker. 2004. Rotifers in different environments of the upper Parana River floodplain (Brazil): richness, abundance and the relationship to connectivity. Hydrobiologia 522: 281290.

APHA 1992. Standard methods for the examination of water and waste water analysis. American Public Health Association, Washington, USA.

Auclair, J.C., J.J. Frenette \& J. Dodson. 1993. Zooplankton community structure in southwestern Quebec lakes: the roles of acidity and predation. J. Plankton Res. 15: 1103-1128

Bidwell, A. \& N.V. Clarke. 1977. The invertebrate fauna of Lake Kainji. Nigeria Field 42: 104-110.

Dejen, E., J.Vijverberg, L. Nagelkerke \& F. Sibbing. 2004. Temporal and spatial distribution of microcrustacean zooplankton in relation to turbidity and other environmental factors in large tropical lake (L. Tana, Ethiopia). Hydrobiologia 513: 39-49.

Downing, J.H. \& F.H. Rigler. 1984. A manual on methods for the assessment of secondary production in freshwaters IBP Handbook No 17. Blackwell Scientific Publication London, England.

Dumont, H.J. 1994. On the diversity of cladoceran in the tropics. Hydrobiologia 272: 27-38.

Egborge, B.M. 1981. The composition, seasonal variation and distribution of zooplankton in Lake Asejire, Nigeria. Rev. Zoo. Afr. 95: 136-180.

Egborge, B.M., C.C. Onwudinjo \& P.C. Chigbu. 1994. Cladoceran of coastal rivers of Western Nigeria. Hydrobiologia 272: 39-46.

Gilbert, J.J. 1988. Suppression of rotifers by Daphnia: a review of the evidence, the mechanism and the effects of zooplankton community structure. Limnol. Oceanogr. 33: 1286-1303.

Hansson, L., S.Gustafsson, K. Rengefors \& L. Bomark. 2007. Cyanobacterial chemical warfare affects zooplankton community composition. Freshwat. Biol. 52: 1290-1301.

Jeje, C.Y. \& C.H. Fernando. 1986. A practical guide to the identification of Nigerian zooplankton. Kainji Lake Research Institute, Niger, Nigeria.

Jeje, C.Y. 1988. A revision of the Nigerian species of the genera Mesocyclops Sars, 1914 and Thermocyclops Kiefer, 1927 (Copepoda: Cycloida). Hydrobiologia 164: $171-184$.

Khan, M.A. \& C.I. Ejike, 1984. Limnology and plankton productivity of Jos Plateau water reservoir, Nigeria, West Africa. Hydrobiologia 114: 189-199.

Korovchinsky, N. 1992. Introduction to the Cladocerans manual for the 1992-1993 International Training Course at University of Gent, Gent, Netherland.

Koste, W. 1978. Rotatoria. Die Radetiere Mitteleuropas. Bestimmungswerk begrundet von Max Voigt. Borntraeger, Stuttgart, Germany.

Masundaire, H.M. 1994. Seasonal trends in zooplankton densities in Sanyati basin, Lake Kariba: multivariate analysis. Hydrobiologia 272: 211-230.

Mergeay, J. Declerck S., D. Verschuren \& L. Meester. 2006. Daphnia community analysis in shallow Kenyan lakes and ponds using dormant eggs in surface sediments. Freshwat. Biol. 51: 399-411.

Moses, B.S. 1979. The Cross River; its ecology and fisheries. p. 365-367. In B.S. Moses (ed). Proceedings of the International Conference on Kainji Lake and river basin development in Africa. 
Mwebaza-Ndawula L. 1994. Changes in relative abundance of zooplankton in two northern Lake Victoria, East Africa. Hydrobiologia 272: 259-264.

Mwebaza-Nadwula, L., S.B.K Sekiranda, \& V. Kiggundu. 2005. Variability in zooplankton community along a section of the Upper Victoria Nile, Uganda. Afr. J. Ecol. 43: 251-257.

Okogwu, O.I. 2008. The physicochemical parameters, plankton and ichthofauna of the Mid-Cross River floodplain ecosystem, South-Eastern Nigeria. Ph.D. Thesis, Department of Zoology, University of Ibadan. Nigeria.

Okogwu, O.I. \& O.A. Ugwumba 2006. The zooplankton and environmental characteristics of Ologe Lagoon, Southwest, Nigeria. Zoologist 3: 86-92.

Onwudinjo, C.C. \& A.B.M. Egborge. 1994. Rotifers of Benin River, Nigeria. Hydrobiologia 272: 87-94.

Ovie, S.I \& H.A. Adeniji. 1994. Zooplankton and environmental characteristics of Shiroro Lake at the extremes of its hydrological cycle. Hydrobiologia 286: $175-182$.

Ovie, S.I. \& S.O. Ovie. 2002. Fish-larval rearing: The effect of pure/mixed zooplankton and artificial diet on the growth and survival of Clarias anguillaris (Linnaeus, 1758) larvae. Afr. J. Aquat. Sci. 17: 69-73.

Pinto-Coelho, R., B. Pinel-Alloul, G. Méthot \& K.E. Havens. 2005. Crustacean zooplankton in lakes and reservoirs of temperate and tropical regions: variation with trophic status. Can. J. Fish. Aquat. Sci. 62: 348-361.
Ravera, O. 1996. Zooplankton and trophic state relationships in temperate lakes. Mem. Ist. Ital. Idrobiol. 54: 195-212.

Saint-Jean, L. 1983. The zooplankton p.199-232. In J.P. Carmouze, J.R. Durand \& C. Leveque (eds), Lake Chad: ecology and productivity of a shallow tropical ecosystem.Nigeria.

Segers, H. 1993. Rotifera of some lakes in the floodplain of the River Niger (Imo State, Nigeria). I. New species and other taxonomic considerations. Hydrobiologia 250: 39-61.

Segers, H., Nwandiaro, S.C. \& H.J. Dumont. 1993. Rotifera of some lakes in the floodplain of the River Niger (Imo State, Nigeria). Hydrobiologia 250: 63-71.

Shannon, C.E. \& W. Weaver. 1949. The mathematical theory of communication. University of Illinois Press, Illinois, USA.

Ueda, H. \& W.J. Reid. 2003. Copepoda: Cyclopoida, Genera Mesocyclops and Thermocyclops Backhuys Publishers, Leiden, Netherlands.

Uku, J.N. \& M.K. Mavuti. 1994. Comperative limnology, species diversity and biomass relationship of zooplankton and phytoplankton in five freshwater lakes in Kenya. Hydrobiologia 272: 251-275.

Williamson, C.E. 1991. Ecology and classification of North American freshwater invertebrates p. 125-188. In J.H. Thorp \& A.P. Covich (eds). New York, Academic Press, USA. 